Avoimesti luettavissa osoitteessa http://journal.fi/ainedidaktiikka

ainedidaktiikka

\title{
Kokemuksellinen oppiminen muotoilupedagogiikan menetelmänä
}

\author{
Päivi Fernström ja Jaana Kärnä-Behm
}

Kasvatustieteiden osasto, Helsingin yliopisto

\begin{abstract}
$\mathbf{y}$
Tarkastelemme tässä tutkimuksessa kokemuksellisen oppimisen hyödyntämistä osana käsityön aineenopettajaksi opiskelevien muotoilupedagogiikkaa. Lähestymme tutkittavaa ilmiötä erityisesti Kolbin (1984; 2005) kokemuksellisen oppimisen teorian pohjalta. Tutkimus on kvalitatiivinen tapaustutkimus (Stage 2008; 2000; Yin 2003), jonka aineisto on kerätty vuosina 2014-2017 kahden eri kurssikokonaisuuden yhteydessä. Toinen kurssi sisältyy käsityötieteen kandiopintoihin $(\mathrm{N}=82)$ ja toinen vastaavien maisterivaiheeseen (N=130). Tutkimustehtävänä oli tarkastella kokemuksellisen oppimisen menetelmää muotoilupedagogisena välineenä näiden kahden tutkimuksessamme tapauksiksi määriteltyjen opintojaksojen valossa. Tutkimuksen tulokset osoittavat omasta elämästä nostettujen kokemusten antavan suunnitteluun varmuutta ja uutta sisältöä tilanteessa, jossa oman identiteetin rakentuminen on usein vielä kesken. Lisäksi kokemuksellinen oppiminen toi työskentelyyn ja oppimisprosessiin vuorovaikutteisuutta niin osallistujien kesken kuin luokkatilanteissa. Opiskelijat kokivat suunnittelemiensa tuotteiden ja tilasuunnittelun saavan enemmän henkilökohtaisia merkityksiä sekä voimauttavan ja rohkaisevan heitä niin suunnittelijoina kuin tulevina opettajina.
\end{abstract}

Muotoilupedagogiikka, kokemuksellinen oppiminen, käsityö, suunnittelu, identiteetti

Lähetetty: 30.5.2017

Hyväksytty 12.9.2018

Vastuukirjoittaja: paivi.fernstrom@helsinki.fi

DOI: 10.23988/ad.64203 


\section{Johdanto}

Tutkimuksemme kohdistuu kokemuksellisen oppimisen hyödyntämiseen käsityön aineenopetuksen muotoilukasvatuksessa. Työssä sovelletaan kokemuksellisen oppimisen teoriaa muotoilukasvatukseen ja konkretisoidaan kokemusten työstämistä ja hyväksikäyttöä käsityön suunnittelu- ja valmistusprosesseissa kahden eri tapauksen avulla: käsityöllisten prosessien alkulähteenä ja merkityksenantajana (i) sekä sisustussuunnittelussa hyödynnettävien muotoiluluotainten käytössä (ii). Tutkimuksen tavoitteena on näiden tapausten valossa analysoida, millaista tietoa kokemuksellinen lähtökohta voi erityisesti suunnittelun yhteydessä tuottaa. Tutkimus vastaa muotoilupedagogiikan haasteeseen tuoda nykyistä enemmän näkyväksi niitä tapoja ja menetelmiä, joilla muotoilua opetetaan ( $\mathrm{Lau}, \mathrm{Ng}$ \& Lee, 2009; Orthell 2015). Lisäksi tutkimuksella vastataan erityisesti käsityön pedagogiikan yhteydessä esiin tuotuun tarpeeseen kehittää uusia käsityön suunnittelumenetelmiä (vrt. Lahti, Seitamaa-Hakkarainen, Kangas, Härkki, \& Hakkarainen 2016; Pöllänen 2009; Gardner 2002). Otamme tutkimuksella kantaa kokemuksellisen oppimisen mahdollisuuksiin oppimisen tukena ja rikastajana myös laajemmin yliopistopedagogiikassa.

Yleisesti muotoilukasvatuksen tavoitteena on ohjata opiskelija kriittiseen lähestymistapaan ja kasvattaa ympäristöä ja esinekulttuuria tiedostavia muotoilun kuluttajia (Nuutinen, Soini-Salomaa \& Kangas 2014). Sen tehtävänä on kannustaa kokeiluihin, aloitteellisuuteen, näkökulman vaihtoon ja omien ideoiden jakamiseen. Tämä tavoite on nähtävissä myös perusopetuksen opetussuunnitelman perusteissa (POP 2014), joiden mukaan opettajat ja oppilaat eivät voi olla pelkästään ennalta määrättyjen tavoitteiden toteuttajia, vaan aktiivisia yhdessä toimijoita, tiedon etsijöitä ja analysoijia. Käsityön muotoilun opetuksessa pyritään paitsi aikaansaamaan esteettisiä ja toimivia artefakteja, myös kehittämään opiskelijan yksilöllisyyttä ja identiteettiä (Nuutinen, Fernström, Kokko \& Lahti 2014; Pöllänen 2009). Oman elämän kokemukset voivat palvella käsityön suunnitteluja valmistusprosessissa sekä yksilöä eheyttävänä tekijänä että konkreettisesti artefaktien sisällökkäämpänä kokonaisuutena (vrt. Malmivirta 2011). Toisaalta esimerkiksi monikulttuurisissa yhteyksissä, maahanmuuttajien omien kokemusten työstäminen ja materialisoiminen konkreettisiksi käsityön tuotteiksi on todettu lisäävän yhteisöllisyyttä ja tuottavan turvallisuuden tunnetta (Malmivirta \& Kivelä 2014).

Tutkimuksessa lähdemme liikkeelle avaamalla työn teoreettisen viitekehyksen. Tutkimuksen lähtökohtana on kokemuksellinen oppiminen (Kolb 1984; 2005), jota on sovellettu käsityöhön liittyvässä muotoilun tutkimuksissa ja pedagogiikassa jo 1990 -luvulta saakka. Yksilön kokemusmaailma, emootiot ja elämykset ovat lähtökohtana käyttäjäkeskeisessä suunnittelussa, kuten myös laajemmin nykyisessä muotoilun tutkimuksessa (Mattelmäki 2006; Millet \& Patterson 2012). Tutkimustehtävänä on selvittää, kuinka käsityönopettajaksi opiskelevien omia kokemuksia voitaisiin käyttää kahdessa suunnittelua sisältävässä opintojaksossa. Tutkimuksen toteutusta käsittelevässä luvussa tuomme esille aineistot, niiden analyysin ja tutkimusstrategian. Tutkimuksen tulososio rakentuu kahden tapauksen raportoinnista ja analyysista suhteutettuna kokemukselliseen oppimiseen. Yhteenveto ja pohdinta -luvussa tuloksia verrataan keskenään 
sekä tutkimustehtävään että kokemuksellisen oppimisen teoriasta nouseviin huomioihin.

\section{Kokemuksellinen oppiminen sekä kokemuksen yh- teys suunnitteluun ja käyttäjälähtöisyyteen}

Kokemuksellisen oppimisen keskeisin teoreetikko on David Kolb (1984; 2005). Kolbin ajattelun lähtökohdat ovat John Deweyn, Kurt Lewinin ja Jean Piagetin ajattelussa (Bergsteiner ym. 2010; Blair 2016; Kolb 1984). Deweyn vuonna 1938 ilmestynyttä Art as experience on käytetty kokemuksellisen oppimisen sovelluksiin erityisesti taidekasvatuksessa. Kolbin teorian mukaan oppimisen prosessissa kiertävät kehämäisenä syklinä konkreettiset kokemukset, pohdiskeleva havainnointi, abstrakti käsitteellistäminen ja aktiivinen toiminta. Lisäksi kokemuksellinen oppiminen perustuu näkemykseen omien kokemusten ja niiden yhteisen jakamisen merkityksestä persoonallisen kasvun ja oppimisen välineenä (Kolb 1984; Räsänen 1997). Holistinen ajattelu ja ihmiskäsitys ovat teorian lähtökohta. Kokemuksellisen oppimisen muodot ja toteutustavat voivat olla hyvin moninaisia, joskin monissa tapauksissa lähtökohtana pidetään edellä kuvattua Kolbin teorian syklimäistä toteutusta (Roberts 2012). Menetelmää on sovellettu eri tavoin 2000-luvun alun käsityön ja muotoilun tutkimuksissa (kts. esim. Fernström \& Laamanen 2005; Ahoniemi 2003; Räsänen 2000; Sava \& Vesanen-Laukkanen 2004). Lisäksi menetelmää on hyödynnetty käsityön ja sen pedagogiikkaan liittyvissä pro gradu -tutkielmissa (Rautiainen 2006; Hentilä 2001; Salo 2000).

Kolbin kokemuksellisen oppimisen mallia on myös kritisoitu. Mallissa kuvatun kokemukseen perustuvan oppimisprosessin eri vaiheet on nähty liian kaavamaisina ja käytetyt käsitteet ajattelua ja toimintaa vastakkain asettelevina (kts. esim. Bergsteiner ym. 2010; Itin 1999). Olipa lähtökohtana sitten Kolb tai jokin muu kokemuksellisen oppimisen teoria, joitakin olennaisia elementtejä tai ehtoja kokemuksellisen oppimisen mukaiselle oppimisprosessille voidaan kuitenkin olettaa. Erilaisista painotuksista huolimatta kokemuksellisen oppimisen keskiössä on aina oppijan aktiivinen osallistuminen oppimisprosessiin (Blair 2016). Andersen, Boud \& Cohen (2000) mukaan kokemuksellinen oppiminen tähtää persoonallisten merkitysten keskeisyyteen oppimisessa. Oppimisessa korostuvat oppijan kannalta omakohtainen prosessiin sitoutuminen, reflektiivisyys oppimisprosessin aikana sekä lopputuloksen ennalta-arvaamattomuus.

Luovuus sekä erilaiset suunnittelu- ja ongelmanratkaisutaidot korostuvat uusissa perusopetuksen opetussuunnitelman perusteissa (2014). Käsityönopetuksiin liittyvissä tutkimuksissa on todettu, että opettajaksi opiskelevat kokevat suunnittelun vaikeaksi tilanteissa, joissa tulevan opettajan on lyhyessä ajassa peruskoulun harjoitustunnilla ohjattava käsityötuotteen suunnittelua. Jälkeenpäin on usein ihmetelty suunnittelun irrallisuutta sekä tuotteesta että tekijästä itsestään (esim. Lahti, Seitamaa-Hakkarainen, Kangas, Härkki \& Hakkarainen, 2016). Suunnittelu on liimattu erillisenä asiana opetukseen eikä selkeää jatkumoa tekemiseen synny. Ajatus siitä, että oikea tieto ja näkemys on jossakin muualla ja että ratkaisut arvioidaan tiedon - ei kokemuksen perusteella - on edelleen melko syvällä opiskeli- 
joiden näkemyksissä (Laamanen 2016). Suunnittelussa tarvittavaa luovuutta ja ongelmanratkaisutaitoa voidaan kuitenkin opettaa (Laamanen 2016; Cross 2011; Lawson 2006). Suunnitteluun liittyvässä luovuudessa Dorst (2006) ja Laamanen (2016) tuovatkin esiin henkilökohtaisten kokemusten ja päämäärien merkityksen prosessiin motivoitumisessa. Näin toimiessaan suunnittelija sitoutuu projektiinsa paremmin.

Tutkimuksemme toinen tapaus kytkeytyi tilasuunnittelun pedagogiikkaan. Paitsi tilasuunnittelun, myös arkkitehtuurin piirissä ihmisen lähiympäristöä, tiloja ja sisustusta koskevan suunnittelun opetukseen on kaivattu lisää kokemuksellisuutta ja tunteita painottavia elementtejä. Näin siksi, että perinteisesti edellä mainittuihin liittyvä suunnitteluprosessi ajatellaan kovin rationaalisesti eteneväksi (Budd 2009). Tilojen suunnittelussa on tärkeää saada tietoa myös siitä, kuinka ihmiset lähiympäristöään käyttävät ja millaisia vaikutuksia tällä on heidän ympäristösuhteeseensa (Vischer 2008).

Käyttäjäkeskeisen suunnittelun myötä kokemukset ja niiden monipuolinen hyödyntäminen osana suunnittelua nousee yhä tärkeämpään rooliin. Käyttäjäkeskeinen suunnittelu on monitieteinen ja -menetelmällinen, käyttäjää suunnittelun eri vaiheissa osallistava työtapa (Millet \& Patterson 2012). Tavallisimpia menetelmiä käyttäjäkeskeisessä suunnittelussa ovat havainnointi, erilaisten prototyyppien työstäminen ja yhteisöllinen suunnittelu (Keinonen, Jääskö \& Mattelmäki 2008). Muotoilussa erilaiset luotaimet (design probes) ovat uutena käyttäjäkeskeisyyteen perustuvana suunnittelu- ja tiedonkeruumenetelmä tulleet joidenkin perinteisempien, usein käyttäjän näkökulman ohittavien menetelmien tilalle (Madden ym. 2014; Mattelmäki 2006; Sanders \& Stappers 2014). Muotoiluluotain on siis väline, jonka avulla pyritään löytämään uusia suunnittelumahdollisuuksia sekä ymmärtämään inhimillisiä tekijöitä kuten asenteita, motivaatiotekijöitä sekä tunteita (Mattelmäki 2006). Luotaamista käytetään yhteisöllisessä suunnittelussa, sillä se kutsuu prosessiin osallistujia pohtimaan ja jakamaan kokemuksiaan erilaisissa suunnittelutilanteissa (Sanders \& Stappers 2014).

Tilan kokemista painottavana analyysimenetelmänä luotainmenetelmää on sovellettu eri tavoin. Kotiympäristöön sijoittuvissa luotaintutkimuksissa on selvitetty jonkin vamman (esim. kuulovamma tai liikuntarajoitteisuus) omaavien, mutta itsenäisesti asuvien asukkaiden asuinympäristön toimivuutta ja heidän asumiseen liittyviä toiveita (Jacobson \& Pirinen, 2007). Lisäksi luotainten avulla on tutkittu kuinka uusi tieto- ja viestintäteknologia voisi edesauttaa kaukana toisistaan asuvien isovanhempien ja lastenlasten vuorovaikutusta (Pedell \& ym. 2014). Julkisiin tiloihin liittyen luotainmenetelmällä on tutkittu esimerkiksi päiväkodin tilojen toimivuutta (Elo 2011) sekä laivaympäristöjen suunnittelua (Ahola 2017). Tähän tutkimukseen liittynyt luotainprosessin soveltaminen analysoidaan tapauksessa kaksi.

\section{Tutkimuksen toteutus ja tutkimusmenetelmä}

Tutkimustehtävänä oli selvittää, kuinka käsityönopettajaksi opiskelevien omia kokemuksia voitaisiin käyttää kahdessa suunnittelua sisältävässä 
opintojaksossa. Tarkastelemme kokemuksellisen oppimisen hyödyntämistä kahden eri tapauksen valossa, joita molempia yhdistää opiskelijoiden oma tutkimuksellinen prosessi kokemuksesta ideaksi, tuotteeksi tai sisustussuunnitelmaksi. Molemmat tutkimukset tehtiin Helsingin yliopistossa käsityötieteen opettajaopiskelijoille suunnatuilla kursseilla ja molempien kurssien opettajat toimivat myös käsillä olevan tutkimuksen tekijöinä.Tutkimusaineisto kerättiin vuosina 2014-2017 kahden eri kurssikokonaisuuden yhteydessä: käsityötieteen aineopintojen Pinnan ilmaisu ja rakenne -kurssien $(\mathrm{N}=82)$ sekä käsityötieteen syventävien opintojen Tutkiva sisustussuunnittelu -kurssin $(\mathrm{N}=130)$ yhteydessä. Tutkimusaineisto koostuu opiskelijoiden portfoliosta ja raporteista, joihin sisältyi kuvallista tuottamista ja reflektointeja sekä opettajan havaintoja ja päiväkirjatyöskentelyä esimerkiksi ryhmäkeskusteluihin liittyen.

Pinnan ilmaisu ja rakenne -kurssilla opiskelijat kokosivat portfolion, joihin liitettiin pohdintoja kokemuksista, niiden käytöstä suunnittelun lähtökohtana ja rikastajana sekä ideoiden siirtämistä tulevaan omaan opetukseen. Kurssilla opiskelijoiden yleisenä tavoitteena oli kurssiin sisältyvin harjoituksin kehittää opiskelijan tieto-taitoja tekstiilisuunnittelun, värjäyksen, kankaanpainannan, kirjonnan ja kudonnan alueilla. Aineisto tältä kurssilta sisältää päiväkirjoja, portfolioreflektioita sekä ryhmäkeskustelujen sisältöjä kurssien yhteydessä. Opiskelijoita pyydettiin kirjaamaan omat havaintonsa jokaisen ryhmäkerran jälkeen ja lopuksi liittämään ne kurssikokonaisuudesta tehtävään portfolioon. Lisäksi opiskelijat liittivät portfolioonsa kaikki luonnokset, piirustukset ja prototyypit, jotka luotiin prosessin aikana. Ryhmäkeskustelut etenivät teemallisesti noin 12 opiskelijan pienryhmissä. Keskusteluja käytiin jokaisen ryhmäkerran alussa edellistä ryhmäkertaa pohtien. Kurssin opettaja toimi keskustelun johdattelijana ja kirjoitti muistiin opiskelijoiden reflektointeja. Tämä kanditason opintojen kurssikokonaisuus kokemuksellisen oppimisen työtavoin muodosti samalla pohjaa Tutkiva sisustussuunnittelu -kurssin käyttäjäkeskeiselle lähestymistavalle.

Maisteriopintojen Tutkiva sisustussuunnittelu -kurssilla opiskelijat suunnittelivat, toteuttivat ja raportoivat luotainprosessin valitsemaansa tilaan. Tila saattoi sijaita joko omassa tai tuttavan lähiympäristössä tai olla jokin julkinen, esimerkiksi kerho- tai liiketila. Luotaamista varten opiskelija suunnitteli ja valmisti tilan käyttäjille erityisen luotainpaketin, joka sisältää tilassa oleskellen ja sitä käyttäen yhden tai kahden viikon ajan tehtäväksi tarkoitettuja tehtäviä (vrt. Mattelmäki 2006). Mattelmäen (2006) mukaan luotainpaketin luotaintehtävillä pyritään tarkentamaan käyttäjän katsetta ja kirjaamaan arkipäivää esim. sosiaalista, esteettistä ja kulttuurista ympäristöä, tarpeita, tuntemuksia, arvoja ja asenteita sekä käsitteellistämään niitä. Luotaintehtävät ovat luonteeltaan sekä kuvailevia että uusia näkökulmia etsiviä; tässä tutkimuksessa ne sisälsivät esimerkiksi valokuvaus- ja piirrostehtäviä, mielikuvakarttojen ja kollaasien tekemistä sekä haastatteluja ja kyselyitä. Tehtävien tarkoituksena on, että niiden avulla käyttäjä pystyy tallentamaan kokemuksiaan sekä ilmaisemaan tässä tapauksessa tilaan liittyviä ajatuksiaan ja ideoitaan. Mattelmäen mukaan (2006; Isen 2004) on tärkeää suunnitella luotaintehtävät kohderyhmän mukaan ja sitouttaa osallistujia riittävästi. Myönteiset kokemukset lisäävät osallistujien ongelmanratkaisukykyä ja joustavuutta luotaintehtävien tekemisessä. Tässä tutkimuksessa luotainpaketti ja siihen liittyvät tehtävät oli 
mahdollista toteuttaa joko fyysisenä tilassa olevana kansiona tai virtuaalisesti tietokoneen tai mobiililaitteiden sovellusten avulla. Luotainprosessit raportoitiin ja vietiin kurssin Moodle -alustalle.

Tutkimusstrategiana työssä on tapaustutkimus (Stage 2000; 2008; kts. myös Yin 2003). Tutkimuksemme kohteena on kokemuksellisen oppimisen soveltaminen muotoilupedagogiikassa, josta nostamme kaksi tapausta lähempään tarkasteluun. Yin (2003) määrittelee tapaustutkimuksen nykyhetkeen ja todelliseen tilanteeseen tarkoittaen sillä empiiristä tutkimusta, joka selvittää nykyistä tapahtumaa tai toimintaa tietyssä ympäristössä. Robert E. Stage (2000; 2008) on jakanut tapaustutkimuksen kolmeen tyyppiin sen mukaan, onko kiinnostuksen kohteena tapaus itsessään, sen välineellinen merkitys vai monien tapauksien vertaaminen paremman ymmärryksen tai teorian rakentamiseksi. Tässä tutkimuksessa rinnastamme kaksi eri nykyhetken todellista tapausta kokonaisvaltaisen ymmärryksen muodostamiseksi. Tapaustutkimuksen avulla pyritään saamaan esiin oleellisia tekijöitä, prosesseja ja vuorovaikutussuhteita, joihin voidaan kohdistaa lisähuomiota erilaisilla tutkimusmenetelmillä. Monien eri tekijöiden selittäessä ilmiötä koetetaan tutkittavasta aiheesta luoda mahdollisimman kokonaisvaltainen, seikkaperäinen ja tarkka kuvaus (Stage 2008).

Opiskelijoilta kerätty aineisto analysoitiin laadullista sisällönanalyysia hyödyntäen (Drisco \& Maschi 2015; Denzin \& Lincoln 2003). Tapaustutkimuksen luonteen mukaan pyrkimyksenämme ei niinkään ole yleistettävyys kuin tutkittavan ilmiön tiheä kuvaus (thick description) (Brailas, Avani, Gkini, Deilogkou, Koskinas \& Alexias, 2017, s. 274; kts. myös Yin 2003). Aineiston analyysista nostetaan esiin konkreettisia havaintoja kokemuksellisen työskentelyn luonteesta ja sen tuloksista. Lisäksi tuodaan näkyville opiskelijoiden tuotoksiin (kirjalliset dokumentit ja tuotteet) liittyviä reflektointeja. Kahden tapauksen kuvailu, analyysi sekä tutkittavan ilmiön merkityksellisten piirteiden löytäminen noudattaa tässä sellaisen tapaustutkimuksen (holistic case study) luonnetta, jossa pyritään ilmiössä vaikuttavien tai sitä rakentavien piirteiden kokonaisvaltaiseen esiintuomiseen (Merriam 2009). Artikkelissa käytetyt aineistoviittaukset ovat opiskelijoiden raporteista, portfolioista ja palautteista. Viittaukset identifioidaan vuosiluvuittain mainiten lisäksi lähde, mistä teksti on lainattu.

\section{Tapaus 1. Kokemuksellinen oppiminen käsityöllisen tuottamisen läh- teenä}

Seuraavassa käsitellään kokemusten hyödyntämistä käsityötieteen aineopintojen Pinnan ilmaisu ja rakenne -kurssikokonaisuuden yhteydessä erityisesti suunnitteluun liitettynä. Analyysissä tuodaan esille tuntien kulku, joita ohjasi Kolbin kokemuksellisen syklin järjestys: konkreettiset kokemukset, pohdiskeleva havainnointi, abstrakti käsitteellistäminen ja aktiivinen toiminta. Sykliä toistettiin useita kertoja. Tarkastelussa pohditaan kokemuksellisuuden merkitystä opiskelijalle sekä opiskelun aikana että tulevassa ammatissa. Tämän jälkeen käsitellään opiskelijoiden kokemukseen liittyviä analyyseja heidän valitsemistaan esineistä ja näiden pohjalta tuotettuja omia käsityöllisiä tuotteita ja kokeiluja. 
Merkityksellisten tuotteiden ja niihin liittyvien aisti- ja tunnekokemusten analysointi

Kolbin (1984) syklisen ja reflektoivan kehän ensimmäinen vaihe on omakohtainen kokemus, jossa kokemus kohdataan aistivoimaisesti. Ennen varsinaista oman tuotteen tai pintakuvion suunnittelua opiskelijat valitsivat jonkin itselleen tärkeän, kokemusta kantavan, tuotteen (konkreettiset kokemukset). Heitä pyydettiin pohtimaan valitsemansa esineen olemusta ja siihen liittyvää kokemuksellista tarinaa (pohdiskeleva havainnointi). Itselle merkityksellisten tuotteiden analyysillä pyrittiin saattamaan opiskelijan tietoisuuden tasolle niitä asioita ja arvoja, joita hänen valitsemassaan esineessä on. Opiskelijat analysoivat esineen äärellä mihin se asettuu hänen omassa elämässä ja mitä se omalla tarinallaan kertoo, miten ne ovat vaikuttaneet tai vaikuttavat hänen elämään:

Kun oikein alan miettiä huomaan, että rikkimenneissä tekstiileissä on lukematon määrä muistoja. Kuka olikaan tehnyt tämän työn ja miksi? Miksi on valittu nämä kuviot, nämä värit ja materiaalit? Mitä kaikkea tekstiili on kokenut ja nähnyt kanssani? Löydän kadonneita palasia elämästäni, joita tämä tekstiili on tietämättäni tai ehkä puolestani kantanut. Nyt olen valmis kuuntelemaan. Nämä käsityöt alkavat elää omassa elämässäni. (Opiskelijan portfolio, kevät 2015.)

Opiskelijoiden valitsemia tuotteita analysoitiin tämän jälkeen yhteisesti ryhmässä kokemuksen näkökulmasta (vrt. Blair 2016; Kolb 1984). Opiskelija toi yhteiseen tarinapöytään kokemuksen, jonka halusi muille jakaa. Yhdessä myös ryhmiteltiin esineet, jolloin voitiin tehdä huomioita siitä, minkälaiset esineet kantoivat kokemuksia ja näin ollen myös opiskelijoiden kokemia tunteita ja merkityksiä (abstrakti käsitteellistäminen). Eniten mainintoja sai tunteikkaisiin tapahtumiin, kuten (1) elämän käännekohtiin liittyvät esineet. Lisäksi merkityksiä löytyi tuotteista, joista on (2) voinut rakentaa jotakin, joilla on voinut (3) kokeilla erilaisia rooleja ja joihin on voinut (4) itkeä ilonsa tai surunsa:

Mummollani oli suruhuivi, tai oikeastaan vain huivi johon kietouduin, kun oikein harmitti. Nimitän sen nyt suruhuiviksi. Mummoni osasi surra ja itkeä kunnolla silloin kun oli surun aika. (Opiskelijan portfolio, kevät 2016.)

Kertoessaan tällä tavalla elämänsä esineistä, opiskelija keräsi itselleen tietoa myös siitä, miten kyseinen esine asettuu hänen arkielämäänsä tai elämänsä kokonaisuuteen. Lisäksi kokemuksen esiin nostava analyysi toi esille esineen kyvyn toimia myös vaikka ajatusten kantajina tai muistin apuvälineinä. 'Tämän huivin kautta muistan mummoni erityisen luonteen. Tässä on vielä jopa hänen tuoksunsa" (Opiskelijan portfolio, kevät 2016). Yksityisessä on aina mukana myös kollektiivista muistia. Siksi esineen ääressä koettujen elämysten on koettu rakentuvan subjektiivisten kokemusten lisäksi kulttuurisista ja sosiaalisista vaikutteista (Forsberg \& Sennefelt, 2014). Opiskelijat korostivat erilaisuuden ymmärtämisen merkitystä omassa tulevassa työssään ja näkivät tärkeänä huomiona erilaisiin kulttuurisiin esineisiin sisältyvät muistot, tarinat tai kollektiiviset merkitykset. Opiskelija ikään kuin tutkijan roolissa ensin keräsi omaa ja muiden kokemustietoa esineiden sisältämistä merkityksistä. 
Ainedidaktiikka 2(2) (2018)

Yhteinen reflektointi ryhmässä ja erilaisten käsitteellistysten muodostaminen koettiin paitsi rakentavaksi, myös haastavaksi. Mielenkiintoisinta opiskelijoiden mielestä oli kuulla muiden kokemuspohdintoja ja huomata yhteneväisyyksiä muiden kanssa. (Konkreettiset kokemukset ja pohdiskeleva havainnointi.) Yhtäläisyydet koettiin joskus jopa huojentaviksi tai voimauttaviksi. Kovin syvällisiin tai vaikeisiin pohdintoihin ei opiskelijoita missään vaiheessa rohkaistu. Omien esine kokemusten tunnistaminen koettiin innoittavaksi ennen kuin lähdettiin suunnittelemaan omia tuotteita.

\section{Käsitteiden ja kokemusten materialisointia}

Koko prosessin suurin vaikeus kohdistui siirtymiseen omasta ja muiden kokemuspohdinnoista varsinaisen oman tuotteen tekemiseen. Ajatusten työstämistä konkretiaksi aloitettiin niillä tavoilla ja materiaaleilla, jotka opiskelija koki itselleen läheiseksi tai helpoksi: kuvat, kollaasit, erilaiset pinnanmuokkaustekniikat, mutta ne olisivat voineet olla myös vaikkapa runoja tai tanssi (aktiivinen toiminta). Erilaisia materialisointeja syntyi kuin dialogiksi vanhoille esineille. Näin muokatut tuotokset kantoivat joko helposti ymmärrettäviä konnotaatioita, tai lähes metaforaksi taipuneita ajatuksia:

Arkisen tuskaiset parittomat sukat. Äitini tuska: kaikki varastetaan. Dementian oire. Koin äitini muistin putoavan syvemmälle ja syvemmälle. Muistisairaan loppuvaiheessa ei ole aikaa eikä paikkaa. Muisti on musta aukko. Kirjon iloisia viestejä äitini parittomiin, mustiin sukkiin, jotka katoavat kuin mustaan aukkoon. (Opiskelijan portfolio, kevät 2016.)

Mummonsa huivin lohtua tuovasta kokemuksesta opiskelija halusi lisäksi toteuttaa jotakin, joka tuotti suurta iloa. Hän pohti materiaalien, värien, erilaisten pintojen ja tekniikoiden merkitystä, ja toteutti iloryijyn, jossa oli mummon kukkapenkki kudottuna värikkäistä makeispapereista, lapsuuden Muumi lakanoista sekä muista iloa tuottaneista materiaaleista. Sitä saattoi pitää seinällä, pöydällä tai tyynynä - siellä, missä kulloinkin iloa eniten tarvittiin. Opiskelija koki saaneensa idean iloryijyyn "kuin lahjana", sillä ilman pohdintaa mummon huivista "en olisi ikinä keksinyt käyttää karkkipapereita tai muuttaa surun iloksi”. Usein juuri tieto esineen mahdollisista yhteyksistä läheisiin ihmisiin saattoi virittää opiskelijan mielikuvituksen jatkamaan tuota yhteyttä:

Siinä (tilkkutyössä) oli mystiikkaa, joka puuttui äitini tarvikepakkaustöistä. Se on side ihmisiin, jotka jollakin tavalla ovat osa minua ja minulla on tunne, että tämä työ kantaa sukuni naisten ajatuksia. Mutta miten minä tai tyttäreni "ajattelemme” tänä päivänä? (Opiskelijan portfolio, kevät 2016.)

Opiskelijan äidinäidiltään perimä kokonaan valkoinen tilkkutyö sai opiskelijan tekemään pinkin vastineen, joka oli omistettu omalle tyttärelle ja jossa oli tyttären konkreettisia lausahduksia. Omien artefaktien tuottaminen tällä tavalla kokemustiedolla personoiden, antoi niille inhimillisiä ominaisuuksia ja vahvan tunnesiteen. Opiskelija saattoi näin kokea esimerkiksi jatkavansa sukunsa naisten tarinaa, joka kerrotaan käsitöiden kautta. Kokemus menneestä muuttui tämän ajan muotoiluksi. Kun kokemukset materialisoitiin tuotteiksi, ne kantoivat jotain olennaista tekijästä itsestään. 
Opiskelijat tiivistivät nyt itse valmistetuista käsitöistä kerättyjä merkityksiä yhteisesti mm. sanoihin läheiset, tuoksu, kartta, kietoutuminen, väri ja koti (abstrakti käsitteellistäminen). Omien tuotteiden käsitteellistäminen liittyi varsin ymmärrettävästi siihen elämään, jota opiskelija juuri nyt eli: läheiset ihmiset; Helsingin ja yliopiston tuoksut; kaupungin, yliopiston ja uuden kodin kartat; kietoutumisen tarve; värien ja kotien yhteydet.

Tärkeänä saavutuksena tällaiselle tekemiselle oli tekijän kasvava luottamus omien havaintojen ja kokemusten tärkeyteen sekä omasta elämästä nostettujen kokemusten merkityksellisyyteen suunnittelussa ja tuotteiden työstämisessä. Opiskelija eheytti itseään tulevana käsityönopettajana ja sai keinoja käsitellä omia kokemuksiaan itselleen läheisellä taidon alalla. Omien kokemusten, työskentelyn ja kokemusten jäsentäminen ja materialisoiminen muiden opiskelijoiden kanssa koettiin avaavan itsessä uusia puolia. Samalla opiskelija oivalsi tekemänsä käsityöt myös esimerkiksi visuaalisen itseilmaisun tai viestin välittäjiksi. Kokemukset, niiden jakaminen muiden kanssa ja työstäminen erilaisilla tavoilla toimivat väylinä omaan suunnitteluun. Myös omien kokemusten joskus yllättäväkin yhdenmukaisuus muiden opiskelijoiden kanssa koettiin eheyttävänä. Opiskelijat kokivat rakentaneensa samalla myös ryhmän identiteettiä sekä kollektiivisia arvoja ja merkityksiä. Esille nostettiin myös moniäänisyyden tärkeys - kaikki kokemukset ja totuudet ovat yhtä tosia ja arvokkaita. Parhaimmillaan kielellinen ja käsityöllinen ilmaus täydensivät toisiaan, mutta vaarana oli usein kuitenkin "pelkkä" oman tekstin kuvittaminen. Siksi ajatuksille on annettavaa aikaa ja keskusteluille jätettävä tilaa (vrt. Kangas 2014).

Opiskelija vie, usein sellaisenaan, oman koulutuksensa aikana opittuja ja kokeiltuja oppimiskokemuksiaan omaan myöhempään työskentelyynsä opettajana (Nuutinen ym. 2016). Siksi opettajan omakohtainen kokemus tällaisesta työskentelystä on tärkeää, jotta ymmärtää sen merkityksen ja pystyy viemään täysipainoisesti kokemuksellista oppimista omaan opetukseen. Prosessin aikana nousi opiskelijan tietoisuuteen ja käsityön kautta näkyväksi niitä moninaisia arvoja, joita opiskelija tulee (tutkivan) opettajan työssä tarvitsemaan. Opiskelijat saatetaan samalla sisälle analysoivaan ja prosessinomaiseen työskentelyyn, joka on myös olennaista tieteellisen ajattelun toteutumiselle. Onnistuessaan se antaa välineitä opiskelijoiden omalle tutkimukselle ja tavoille lähestyä ajankohtaisesti suunnittelun ja valmistuksen olemusta opetustyössä. Ajatuksena on, että aloitteleva opettaja hakeutuisi helpommin muiden opettajien kanssa yhdessä opettamisen menetelmiin (co-teaching).

Edellä tarkasteltiin kokemuksen hyödyntämistä suunnittelun ja käsityöllisen tuottamisen rikastajana sekä oman käsityöntekijän identiteetin vahvistajana opiskelijan ensimmäisten kurssien aikana perus- ja aineopinnoissa. Lähtökohdan ajatuksena on ollut lujittaa opiskelijan uskoa omaan suunnitteluun. Kun opiskelija tämän jälkeen suunnittelee ja tekee tuotteita muille, on helpompi asettua toisen rooliin (vrt. Lawsonin, 2006, ajatus keksityistä narratiiveista). Seuraavassa perehdytään kokemuksen hyödyntämiseen tila- ja sisustussuunnittelussa, jossa kokemuksellinen lähtökohta linkittyy osaksi käyttäjäkeskeistä suunnittelua. 


\section{Tapaus 2. Kokemuksellinen oppiminen tila -ja sisustussuunnittelussa}

Tutkimustulosten tarkastelu etenee tässä luvussa kokemuksellisuuden hyödyntämisestä tilan toiminnallisuuden analysointiin jatkuen sen jälkeen opiskelijoiden käsitteellistyksiin siitä, millaista tietoa tilan käyttäjän kokemukseen nojaava menetelmä voi sisustussuunnittelun yhteydessä tuottaa. Lisäksi tuodaan esille opiskelijoiden ideoita siitä, mihin muihin aihepiireihin kuin sisustukseen tätä kokemuksellisuudesta lähtevää menetelmää voisi käyttää. Opiskelijat kehittivät myös pedagogisia sovelluksia omakohtaisten luotainprosessiensa pohjalta.

Valtaosa opiskelijoiden toteuttamista luotainprosesseista kohdistui heitä lähellä olevaan kotiympäristöön. Opiskeleva nuori on usein asumisen suhteen eräänlaisessa välitilassa, jossa kodiksi koettu tila on kahtiajakautunut. Nuori ei asu enää vakituisesti lapsuudenkodissa, mutta toisaalta mahdollista opiskelija-asuntoakaan ei välttämättä koeta "oikeaksi" kodiksi. Yksilön elämänkulussa kodit voidaankin ymmärtää “jatkumona ja murroksina, monina koteina ja niiden peräkkäisyyksinä, mutta myös samanaikaisina ja rinnakkaisina koteina" (Vilkko 2010a, s. 22; kts. myös Johansson \& Saarikangas 2009). Paitsi fyysinen tila, koti on myös "tunnetila, jossa elämme arkeamme, johon palaamme ja josta lähdemme" (Vilkko 2010b, s. 9). Edellä mainittu kokemus kodin väliaikaisuudesta tuli esille opiskelijoiden luotainprosesseissa.

\section{Tilankäyttöön ja tilan tunnelmaan liittyvien kokemusten analysointi}

Tilankäytöllä tarkoitetaan luotainprosessin yhteydessä konkreettista ja päivittäistä tilassa olon määrää sekä tilassa liikkumisen tapoja. Tässä tutkimuksessa tilankäytön kokemuksellisuutta painottavalla analyysillä pyrittiin selvittämään tilan funktionaalisia piirteitä; sitä millaista tilassa on liikkua ja onko esimerkiksi tilan kalustus järjestetty sen käyttötarkoitukseen nähden optimaalisella tavalla. Tilankäytön analyysia voidaan toteuttaa hyvin konkreettisella tavalla esimerkiksi merkitsemällä eri värisillä post-it lapuille päivittäisiä havaintoja tilan käytöstä tilan eri osa-alueille tai havainnollistamalla niitä suurennettuun tilaa kuvaavaan pohjapiirrokseen.

Tunnelma ilmaisee tilan erityistä luonnetta ja identiteettiä ja sitä voidaan tietoisesti muokata, luoda ja tuottaa (Forss 2007). Tilan tunnelman kokemuksellisuutta painottavassa analyysissa tilaa skaalattiin esimerkiksi erilaisten vastinparien, kylmä-lämmin, valoisa-synkkä, vuorovaikutuksessa -erityksessä jne., avulla. Tilan tunnelmasta tehtiin myös kollaaseja, joilla voidaan pyrkiä paitsi toteamaan olemassa oleva tilanne, myös visioimaan tilan tunnelmaa ideaalitilanteessa. Tilan tunnelmaan vaikuttavat sen materiaalit, joita analysoitiin paitsi havainnoimalla, myös valokuvaamalla tai materiaali- ja värikarttoja tehden. Analysoitaessa tilan tunnelmaa nimenomaan kokemuksen näkökulmasta, tultiin tietoiseksi siihen liittyvistä elämyksellisistä tekijöistä, kuten epämiellyttävästä äänimaailmasta tai tuoksusta. Tilankäytön kokemuslähtöisellä analyysillä selvisi esimerkiksi, ettei tilaa oikeastaan käytetä siinä tarkoituksessa, kun se on suunniteltu. Tai että työtila työpöytineen on itse asiassa tarpeeton, sillä työskentely on siirtynyt sohvalle tai asunnon muihin huoneisiin. Alkuoletukset tilankäytön luonteesta ja sen toiminnoista siis tarkentuivat prosessin myötä.

Karjalaisen (2004) mukaan ihmisen arkipäiväiseen ympäristöön kietoutuu erilaisten merkitysten monimutkainen verkko, eletty ympäristö, 
josta muodostuu henkilökohtainen ja persoonallinen paikka maailmassa. Paikan kokemiseen liittyvät myös fantasiat eli mielikuvituksemme kyky ylittää fyysisiä rajoja osana jokapäiväistä paikan kokemisen kokonaisuutta. Paikka on siten inhimillisen tulkinnan ja merkityksenannon tulos (Karjalainen 2007). Mikäli luotaamista oli toteutettu lasten kanssa kävi ilmi, kuinka lapsen paikoille ja esineille antamat merkitykset ovat vielä joustavia ja tilannesidonnaisia. Toisaalta joihinkin luotainprosesseihin osallistuneet lapset toivat esiin oman huoneen paikkana hyvin merkityksellisenä. Tätä oman tilan erityistä merkitystä voidaan vahvistaa suunnittelulla, jossa myös lapsen näkemykset tilan käyttäjänä tulevat kuulluksi.

Kokemusten jakaminen vuorovaikutuksen ja yhteisöllisyyden edistäjänä

Koti on yhden tai useamman perheen jäsenen kesken jaettu tila, jolloin kotiin liittyvissä suunnittelutilanteissa voisi tilan ja sisustuksen suunnittelun ajatella olevan luonteeltaan demokraattista. Tutkimuksessa kävi kuitenkin ilmi, että useimmiten kotiin liittyvien ympäristöjen suunnittelusta päävastuun on kantanut perheen äiti, eivätkä sisustukseen liittyvissä asioissa esimerkiksi miehen tai lasten mielipiteet ole juurikaan tai lainkaan, tulleet kuulluksi. Sisustaminen ja siitä kiinnostuneisuus onkin perinteisesti nähty varsin feminiinisenä alueena (Edwards 2011; Johansson \& Saarikangas 2009; Havenhand 2004). Tarve yhteisöllisempään kodin tilojen tai sisustuksen suunnitteluun tuli kuitenkin luotaamisessa varsin konkreettisesti esiin:

Projektin ansiosta perhe sai yhteistä tekemistä ja ajateltavaa. Lasten into oli valtava, kun myös he pääsivät osallistumaan suunnitteluun. Ideat olivat villejä, mutta pienellä jalostuksella varmasti toteutuskelpoisia. Enpä olisi itse keksinyt, että huoneen seinään voisi piirtää tai maalata puun ja rakentaa siihen majan. Mahtavaa mielikuvituksen käyttöä! (Opiskelijan luotainraportti, kevät 2016)

Luotaaminen oli myös mahtava keino eri osapuolten kertoa oma mielipiteensä tilan toiveista, eri tavoilla, ilman että kenellekään tulee syyllinen olo siitä, että jokin on niin kuin se on. Saimme erinomaisen keskustelun aikaiseksi ja huone tullaan muuttamaan toiveiden mukaiseksi. (Opiskelijan luotainraportti, kevät 2017)

Vuorovaikutus tilaan ja sisustukseen liittyvien kokemusten äärellä johti perheen sisällä varsin usein pohtimaan myös käsitteiden subjektiivista merkitystä. Esimerkiksi aikaisemmin kuvatussa skaalaustehtävässä etenkin pariskunnat saattoivat tulla johtopäätökseen, että tilaan liittyvänä ominaisuutena se mikä on toiselle "valoisa", onkin toiselle "synkkä". Tai että värin erityisenä ominaisuutena "lämmin" voi tarkoittaakin muille asukkaille jotain aivan muuta kuin opiskelija-tutkija oli olettanut. Vuorovaikutustilanteet luotaintehtävien äärellä saivat myös uusia muotoja. Luotaintehtävien ympärille järjestettiin illalliskutsuja, jossa vieraat osallistuivat tehtävien tekemiseen tai lastenhuoneessa oleva luotain sisälsi sisustusta analysoivia pelejä, johon myös lapsen kaverit saivat osallistua. Kokemuksellinen lähtökohta siis lisäsi ja moninaisti vuorovaikutusta luotaukseen osallistuvien kesken. 
Ainedidaktiikka 2(2) (2018)

Oma kokemus väylänä uudelle: pedagogisia ja muita sovelluksia

Luotainprosessin suunnittelun ja toteutuksen jälkeen opiskelijoita pyydettiin pohtimaan - nyt omaan kokemukseen perustuen, kuinka luotainmenetelmää voisi soveltaa joko pedagogisesti tai muille sovellusalueille. Luonnollisesti oman luotainprosessin jälkeen sovelluskohteita löytyi runsaasti erilaisten tilojen suunnitteluun: tilojen käyttötarkoituksen muutoksiin tai sen viihtyisyyden analyyseihin kuten myös erilaisten julkisten/ yhteisöllisten tilojen (esim. päiväkodit, palvelutalot, kerhotilat, sairaaloiden odotustilat jne.) suunnitteluun ja sisustamiseen. Lisäksi nähtiin edullisena tilanne, jossa luotainprosessi toteutetaan ennen remonttia tai asunnon vaihtoa selventämään sitä, mitä asujat tulevaisuuden kodilta ja asumiselta oikein odotetaan. Omaan kokemukseen perustuen löydettiin sovellusarvoa myös ihmisten välisten suhteiden analyysiin esimerkiksi tiimien rakentamisessa työpaikoilla tai oman arjen ja elämäntilanteen kirkastamiseen (life coaching).

Opiskelijat pohtivat ja kehittivät luotainmenetelmästä myös pedagogisia sovelluksia. Sovellusarvoa löydettiin niin aikuisopetuksen sisustuksen aihepiireihin, kuin myös yläkoulun käsityönopetukseen, jossa esimerkiksi oman huoneen sisustaminen tai jonkin sisustustuotteen suunnittelu sinne voidaan aloittaa luotainmenetelmää hyödyntämällä. Kuluttajakasvatuksellisena sisältönä ideoitiin oman vaatekaapin sisällön luotausta. Vaatetukseen liittyen sovellusarvoa nähtiin myös oman tyylin löytämisessä:

Ainedidaktisessa projektityössä lähdimme yhdessä ryhmän kanssa kehittämään "tyyliluotainta”, jossa erilaisten tehtävien avulla yläkoululaiset voisivat tulla paremmin tietoisiksi omasta tyylistään ja siihen vaikuttavista tekijöistä....Olen miettinyt myös luotaimen käyttöä omassa gradussani käyttäjätiedon ja kokemusten keräämisessä. Nuoren voisi olla helpompaa tuoda ajatuksiaan esille erilaisten tehtävien kautta kuin haastattelun avulla. (Opiskelijan luotainraportti, kevät 2017)

Aikaisemmin tässä artikkelissa toimme esiin käsityötuotteisiin liittyvän suunnittelun riittämättömyyttä sekä toisaalta haasteellisuutta saada suunnittelusta selkeä jatkumo tuotteen valmistukseen (kts. myös Lahti, Seitamaa-Hakkarainen, Kangas, Härkki, \& Hakkarainen, 2016; Pöllänen 2009; Gardner 2002). Pyrkimys suunnittelun osuuden kasvattamiseen tulee esille niin nykyisissä peruskoulun opetussuunnitelman perusteissa (2014) kuin myös opiskelijoiden taholta:

Olemme opettajaopiskelijoina kokeneet, että tuotteen suunnittelun olevan pikemmin pakollinen aikaa kuluttava osio kuin oppimista ja työskentelyä ohjaava tärkeä vaihe. Koulukäsitöissä suunnittelun vähäisyys näkyy usein siinä, ettei oppilas arvostaa omaa työtään ja viitsi nähdä vaivaa sen eteen. Kun tuote on hyvin suunniteltu ja perustuu käyttäjänsä tarpeisiin, tulee myös työskentelystä todennäköisemmin mielekästä ja valmiista tuotteesta todella myös käyttökelpoinen ja pitkäikäinen." (Opiskelijan luotainraportti, kevät 2017)

Suunnittelun osuuden kasvattamisella ja tulevan käyttäjän tarpeiden huomioimisella voidaan edellä esitetyn mukaan todeta olevan merkittävä vaikutus myös siihen, että tuotteesta tulee käytettävä ja merkityksellinen. 


\section{Yhteenveto ja pohdinta}

Asetimme tavoitteeksi tässä artikkelissa tutkia ja analysoida kokemuksellista oppimista ja sen hyödyntämistä yliopistollisessa muotoilupedagogiikassa. Analyysimme kohdentui kahteen tapaukseen käsityön aineenopettajakoulutuksen kandidaatti- ja maisterikoulutuksien tasoilla. Vaikka substanssina tässä artikkelissa on käsityö, ovat tutkimuksen tulokset hyödynnettävissä myös laajemmin muotoilun pedagogiikkaan ja sen tutkimukseen. Pyrkimyksenämme ei tässä tutkimuksessa ollut yleistettävyys vaan pikemmin tutkittavien pedagogisten tapausten tiheä kuvaus (Brailas, Avani, Gkini, Deilogkou, Koskinas \& Alexias, 2017, s. 274; kts. myös Yin 2009).

Kokemuksellisen oppimisen pedagogiikka sitoutui artikkelissa kokemuksen ymmärtämiseen moniulotteisena ilmiönä sekä välineenä, jonka avulla erityisesti suunnittelun osuutta käsityön muotoiluprosessissa voidaan rikastaa ja syventää. Kuten tutkimuksen johdannossa totesimme, käsityön pedagogiikassa suunnittelun riittämättömyys ja toisaalta myös sen haasteellisuus (vrt. Lahti, Seitamaa-Hakkarainen, Kangas, Härkki, \& Hakkarainen 2016; Pöllänen 2009; Gardner 2002) ovat entiteettejä, joihin tutkimuksen ja käytännön sovellusten avulla on tulevaisuudessa kiinnitettävä yhä enemmän huomiota. Myös perusopetuksen opetussuunnitelman perusteet (2014) käsityönopetuksen eri vuosiluokilla edellyttävät suunnittelun osuuden vahvistamista. Tähän tarpeeseen on pyritty vastaamaan myös Helsingin yliopiston käsityönopettajan koulutuksessa muodostamalla erillinen 5 opintopisteen opintojakso Suunnittelun opettaminen. Myös tuossa opintojaksossa kokemuksellinen oppiminen on yhtenä lähestymistapana mukana.

Työssään opettaja kohtaa erilaisista taustoista ja tilanteista tulevia lapsia ja nuoria. Tämä tutkimus osoitti, että muutosten keskellä elämistä ja niiden kokemista voidaan valjastaa myös oppimisen ja opetuksen kohteeksi ja voimavaraksi. Kokemuksellisen oppimisen sovelluksissa erityisesti aikuisten kanssa on todettu, että todellisesta ja eletystä elinpiiristä ammentaminen toimii oppimisprosessissa vahvana motivoijana (Blair, 2016; Chisolm, Harris, Northwood \& Johnrendt, 2009). Tämä tuli esille tapauksessa 1., jolloin opiskelijat kokivat voimaantuneensa saadessaan tuoda esiin omia kokemuksiin perustuvia tarinoitaan. Lisäksi kokemuksellisen oppimisen prosessi avarsi heidän mielestään ymmärrystä muiden ajattelun moninaisuudesta. Vastaavasti tapauksessa 2. todettiin, kuinka tämänhetkinen opiskelijan oman asuinympäristön kokemuksellinen analyysi auttoi hahmottamaan asumiseen liittyviä arvoja ja siihen liittyviä toiveita ja lähtökohtia myös tulevaisuudessa.

Molemmissa tapauksissa opiskelijoiden reflektioista nousi Andersenin, Boudin \& Cohenin (2000) tutkimuksen tapaan prosessiin sitoutumisen, reflektiivisyyden ja lopputuloksen ennalta-arvaamattomuuden elementit. Persoonallisten merkitysten hyväksikäyttö koettiin rohkeutta ja voimaa antavana tekijänä. Kolbin $(1984 ; 2005)$ kokemuksellisen oppimisen vaiheista opiskelijoiden konkreettiset kokemukset liittyivät tutkimuksessa sekä esineisiin että tiloihin. Tilasuunnittelun kohdalla merkityksellisiä olivat myös muiden kuin opiskelijoiden kokemukset tilasta. Pohdiske- 
levan havainnoinnin kohdalla etenkin kokemusten ympärillä käydyt keskustelut ja vuorovaikutus luokkatilanteessa rikastivat opiskelijan käsityksiä ja havaintoja ympäröivästä maailmasta molemmissa tapauksissa. Erityisesti luotainmenetelmää koskevissa tutkimuksissa on todettu sen lisäävän vuorovaikutusta niin suunnittelijan ja luotainprosessiin osallistujien kuin eri osallistujien kesken (Madden ym. 2014; Mattelmäki 2006).

Abstraktia käsitteellistämistä harjoiteltiin tapauksen 1. refelektioissa ensiksi esineisiin ja toiseksi omien tuotteiden kokemiseen liittyvien metakäsitteiden muodostamisena. Tapauksessa 2. kokemusten käsitteellistäminen liittyi erityisesti luotainraportin kirjoittamiseen prosessin kuvauksen yhteydessä. Kävi myös ilmi, ettei tilaan liittyviä piirteitä ja sitä kuvaavia käsitteitä koeta useinkaan samalla tavalla: tila, joka on toiselle synkkä on toiselle valoisa. Keskustelut tilan muiden kokijoiden kanssa avasivat tilankäyttöön uusia näkökulmia. Aktiivisen toiminnan vaihe liittyi tapauksessa 1. oman harjoituksen tai tuotteen valmistamiseen, ja tapauksessa 2. luotaintehtävien suunnitteluun ja toteutukseen sekä itse luotaamiseen siihen liittyvin toiminnoin. Viimeksi mainitussa tapauksessa aktiivinen toiminta (esim. kollaasien teko, tilankäytön toiminnalliset analyysit, valokuvaus ym.) tilan kokemisessa koettiin uusina ja elämyksellisinä tapoina analysoida tilaa. Tapauksen 1. yhteydessä kokemusten ja käsitteellistysten muuttaminen aktiiviseksi toiminnaksi, esimerkiksi oman käsityöllisen tuotteen tekeminen, koettiin ensin vaikeaksi, mutta dialogisuus kokemusta kantavan tuotteen ja itse tehdyn tuotteen välillä sitä vastoin helpottavaksi. Oma tuote sai vahvan tunnesiteen, jota ei aikaisemmin oltu näin koettu.

Tutkimuksessa todettiin kokemuksellisen oppimisen edesauttavan opiskelijaa tekemään merkityksellisiä tuotteita ja niihin liittyviä suunnitelmia. Tämä merkityksellisyyden kokemus vahvistui molemmissa tutkimuksen tapauksissa. Onkin perusteltua huomioida kokemuksellisuuden merkitystä entistä enemmän niin osana nykyistä muotoilupedagogiikka (Frascara \& Guillermina 2012) kuin myös laajemmin, esimerkiksi ihmisen lähiympäristön suunnittelussa (vrt. Virscher 2008). Kokemusperäisen tiedon hankinta asiantuntijoilta kuin myös ei-asiantuntijoilta hyödyttää muotoilun prosesseja monin eri tavoin (Sanders \& Stappers 2014). Tämä puolestaan lisää tarvetta kehittää sekä uusia että jo olemassa olevia kokemuksellisuuteen nojaavia suunnittelumenetelmiä. Opiskelijoiden reflektiot ja uudet sovellusideat tarjoavat kokemuksellisuuden oppimisen tutkimukselle konkreettisia jatkotutkimusaiheita myös oppiainerajoja ylittäen.

\section{Lähteet}

Ahola, M. (2017). Tracing Passenger Safety Perception For Cruise Ship Design. Aalto University. Aalto Arts Books.

Ahoniemi, P. (2003). Taidekokemuksesta omaksi vaatteeksi - vaatetuksen suunnitteluprosessi identiteetin rakentajana. Teoksessa Ritva Koskennurmi-Sivonen \& AnnaMari Raunio (toim.), Kotitalous - ja käsityötieteiden laitoksen julkaisuja 8. Helsinki: Helsingin yliopisto.

Andersen, L., Boud, D. \& Cohen, R. (2000). Experience-based learning. Teoksessa G. Foley (toim.), Understanging adult education and training. St leonards (ss. 225239). Australia: Allen \& Unwin.

Bergsteiner, H., Gayle, C. A., \& Neumann, R. (2010). Kolb’s experiential learning model: Critique from a modelling perspective. Studies in Continuing Education. 32(1), 29-46. 


\section{Ainedidaktiikka 2(2) (2018)}

Blair, Denise, J. (2016). Experiential learning for Teacher Professional Development at Historic Sites. Journal of Experiential Education, 39(2), 130-144.

Brailas, A., Avani, S.-M., Gkini, C., Deilogkou, M.-A., Koskinas, K., \& Alexias, G. (2017). Experiential learning in action: A collaborative inquiry. The Qualitative Report, 22(1), 271-288. http://nsuworks.nova.edu/tqr/vol22/iss1/15

Chisholm, C. Harris, M. Northwood, D. Johnrendt, J. (2009). The Characterisation of Work-Based Learning by Consideration of theTheories of Experiential Learning. European Journal of Education, 44(3), 319-337. https://doi.org/10.1111/j.1465-3435.2009.01394.x

Cross, N. (2011). Design thinking. Understanding how designers think and work. Oxford: Berg. https://doi.org/10.5040/9781474293884

Dorst, K. (2006). Understanding Design. Amsterdam: BIS Publishers.

Drisko, J. W. and Maschi, T. (2015). Qualitative Content Analysis. Teoksessa J. Drisko and T. Maschi (toim.), Content Analysis, Oxford Scholarship Online.

Edwards, C. (2011). Interior Design: A Critical Introduction, Oxford:Berg.

Fernström, P. \& Laamanen, T-K. (2006). Tarinat ja mielikuvat käsityön suunnittelun lähtökohtina. Teoksessa L. Kaukinen \& M. Collanus (toim.), Tekstejä ja kangastuksia: puheenvuoroja käsityöstä ja sen tulevaisuudesta. Akatiimi, 137-148.

Forss, A-M. (2007), Paikan estetiikka. Eletyn ja koetun ympäristön fenomenologiaa. Helsinki: Yliopistopaino.

Forssberg, A.M.\& Sennefelt, K. (toim.). (2014). Fråga föremålen: handbok till historiska studier av materiell kultur. Lund: Studentlitteratur.

Frascara, J. \& Guillermina, N. (2012). What is missing in the design education today? Visible Language, 46(1/2), 36-53.

Gardner, E. (2002). Graft education in Finland. Definitions, rationales and the future, International Journal of Art and Education, 21(2), 32-145.

Havenhand, Lucinda K. (2004). 'A view from the margin', Design Issues, 20(4), 32-42.

Hentilä, (2001). Kädentaidot osana kuntoutusta: ohjaajan näkökulma. Helsingin yliopisto. Kasvatustieteiden tiedekunta. Julkaisematon kasvatustieteen syventävien opintojen tutkielma.

Isen, Alice M. (2004). 'Some perspectives on positive feelings and emotions: Positive affect facilitates thinking and problem solving'. Teoksessa A. S. R. Manstead, F. Nico and F. Agneta (toim.), Feelings and Emotions: The Amsterdam Symposium (ss. 263-281). New York: Cambridge University Press. https://doi.org/10.1017/CBO9780511806582

Itin, C. M. (1999). Reasserting the Philosophy of Experiential Education as a Vehicle for Change in the 21st Century. Journal of Experiential Education, 22(2), 91-98. https://doi.org/10.1177/105382599902200206

Jacobson, S. \& Pirinen, A. (2007). Disabled persons as lead users in the domestic environment. Designing Pleasurable Products and Interfaces (ss. 158-67). Helsinki. University of Art and Design. https://doi.org/10.1145/1314161.1314175

Johansson, H. \& Saarikangas, K. (2009). 'Introduction. Ambivalent Home', in H. Johansson and K. Saarikangas (toim.), Homes in Transformation: Dwelling, Moving, Belonging (ss. 9-38). Helsinki: SKS.

Karjalainen, P. (2004). Ympäristö ulkoa ja sisältä: Geografiasta geobiografiaan. Teoksessa R. Mäntysalo (toim.), Paikan heijastuksia. Ihmisen ympäristösuhteen tutkimus ja repsesentaation käsite (ss. 49-68). Jyväskylä: Atena Kustannus,

Karjalainen, P. (2007). Paikoista maisemiin: Ympäristön eletty mieli. Teoksessa Y. Sepänmaa, L. Heikkilä-Palo \& V. Kaukio (toim.), Maiseman kanssa kasvokkain (ss. 50-57). Helsinki: Maahenki..

Kolb, D. (1984). Experiential learning. Experience as the source of learning and development. Englewood Cliffs, NJ: Precentice Hall.

Kolb, A., \& Kolb, D. (2005). The Kolb Learning Style Inventory-Version 3.1. 2005 Technical Specifications. Experience Based Learning Systems. Luettu 11.8.2015 http://learningfromexperience.com/media/2010/08/tech_spec_lsi.pdf.

Kouhia, A. (2016). Unraveling the meanings of textile hobby crafts. Helsinki: Unigrafia.

Lahti, H., Seitamaa-Hakkarainen, P., Kangas, K., Härkki, T. and Hakkarainen, K. (2016). 'Textile teacher students' collaborative design processes in a design studio setting', Art, Design \& Communication in Higher Education, 15(1), 35-54. 


\section{Ainedidaktiikka 2(2) (2018)}

Lawson, B. (2006). How Designers Think? The Design Process Demystified. Oxford: Elsevier. https://doi.org/10.4324/9780080454979

Keinonen, T., Jääskö, V. and Mattelmäki, T. (2008). 'Three-in-one user study for focused collaboration', International Journal of Design, 2(1), 1-10.

Laamanen, T.-K. (2016). Generating and transforming representations in design ideation. Helsinki: University of Helsinki.

Lau, K. W., Ng, M. C. F. and Lee, P. Y. (2009). 'Rethinking the creativity training in design education: A study of creative-thinking tools for facilitating creativity development of design students', Art, Design \& Communication in Higher Education, 8(1), 71-84.

Madden, D., Cadet-James, Y., Atkinson, I. and Lui, F. (2014). 'Probes and prototypes: A participatory action research approach to codesign', CoDesign, 10(1), 31-45.

Malmivirta, H. (2011). Taide siltana sosionomiksi (AMK) kasvamiselle Toimintatutkimus taide- ja ilmaisuaineiden kehittämisestä postmodernin taidekasvatuksen suuntaan Oulun seudun ammattikorkeakoulun sosiaalialan koulutusohjelmassa vuosina 2001-2004. Tampere: Tampereen Yliopistopaino Oy - Juvenes Print.

Malmivirta, H. ja Kivelä, s. (2014). Taiteesta ja kulttuurista avaimia aivoterveyteen. Palvelumallien kehittämistä kansalaislähtöisesti. http://julkaisut.turkuamk.fi/isbn9789522164940.pdf Luettu 4.6.2018.

Mattelmäki, Tuuli (2006). Design Probes, Helsinki: Publication Series of the University of Art and Design A 69.

Millet, Barbara and Patterson, Patrick (2012). 'User-centered design', in S. Garner and C. Evans (toim.), Design and Designing (ss. 129-43). A Critical Introduction, UK: Berg.

Merriam, Sharan B. (2009). Qualitative Research: A Guide to Design and Implementation, San Francisco, CA: Jossey-Bass Inc.

Nuutinen, A., Fernström, P., Kokko, S. \& Lahti, H. (2014). Suunnittelusta käsin. Käsityön tutkimuksen ja opetuksen vuoropuhelua. http://hdl.handle.net/10138/153027

Nuutinen, Soini-Salomaa \& Kangas (2014). Käsityön tulevaisuuksia - elinikäisen osaamisen visioita, haasteita ja mahdollisuuksia. Teoksessa S. Karppinen, A. Kouhia \& E. Syrjäläinen (toim.), Kättä pidempää: Otteita käsityön tutkimuksesta ja käsitteellistämisestä (ss. 203-219). Helsinki: Helsingin yliopisto, Opettajankoulutuslaitos.

Nuutinen, A., Räisänen, R. \& Fernström, P. (2016). Material and Surface - Course synergy as channel towards more encompassing view of learning. Techne Series: Research in Sloyd Education and Craft Science, 23(1), 30-48.

Orthell, Bryan D. (2015). Implications of design thinking in for teaching, learning and inquiry. Journal of Interior Design, 40(3), 1-20.

Pedell, S., Vetere, L., Miller, T., Howard, S. and Sterling, L. (2014). 'Tools for participation. Intergenerational technology Design for the home', International Journal of Design, 8(2), 1-14.

Perusopetuksen opetussuunnitelman perusteet (POP) (2014). Helsinki: Opetushallitus

Pöllänen, S. (2009), 'Contextualising craft: Pedagogical models for craft education', International Journal of Art and Design Education, 28(3), 249-60. https://doi.org/10.1111/j.1476-8070.2009.01619.x

Rautiainen, M. (2006). "Valmis tuote on aina eheyttävä kokemus": käsityön terapeuttisuus mielenterveystyön ammattilaisten käsityksissä. Helsingin yliopisto. Kasvatustieteiden tiedekunta. Julkaisematon kasvatustieteen syventävien opintojen tutkielma.

Roberts, J. W. (2012). Beyound learning by doing: Theoretical currents in experiential education. New York: Routledge.

Räsänen, M. (2000). Sillanrakentajat: Kokemuksellinen taiteen ymmärtäminen. Helsinki: University of Art and Design.

Salo, T. (2000). Elämyksellisestä oppimisesta ilmaisulliseen käsityöprosessiin: kokemuksellinen oppiminen peruskoulun käsityönopetuksessa. Kasvatustieteiden tiedekunta. Julkaisematon kasvatustieteen syventävien opintojen tutkielma.

Sanders, Elizabeth B.-N. \& Stappers, Pieter J. (2014). 'Probes, toolkits and prototypes: Three approaches to making in codesigning', CoDesign, 10(1), 5-14.

Sava, I. \& Vesanen-Laukkanen, V. (2004). Taiteeksi tarinoitu oma elämä. Jyväskylä: PSKustannus. 


\section{Ainedidaktiikka 2(2) (2018)}

Suomen muotoilukasvatusseura. Luettu 4.6.2018. http://www.muotoilukasvatus.info/muotoilukasvatus/

Stage, R. (2000). The Case Study Method in Social Inguiry. Teoksessa Roger Gomm, Martyn Hammersley \& Peter Foster (toim.), Case study method. Key issues, key texts. London: Sage, 19-26.

Stage, R. (2008). Qualitative Case Studies. Teoksessa N.K. Denzin \& Y. S. Lincoln (toim.), Strategies of Qualitative Inquiry (ss. 119-149). Thousand Oaks, CA: Sage.

Vischer, Jacqueline C. (2008). 'Towards a user-centered theory of the built environment', Building Research and Information, 36(3), 231-240.

Vilkko, A. (2010a). Kohteena koti. Teoksessa Anni Vilkko, Asko Suikkanen \& Johanna Järvinen-Tassopoulos (toim.), Kotia paikantamassa (ss. 11-34). Rovaniemi: Lapin yliopistokustannus.

Vilkko, A. (2010b). Lukijalle. Teoksessa Anni Vilkko, Asko Suikkanen \& Johanna Järvinen-Tassopoulos (toim.) Kotia paikantamassa (s. 9). Rovaniemi: Lapin yliopistokustannus.

Yin, R. K. (2003). Case Study Research. Design and Methods. Thousand Oaks CA: Sage. 